\title{
RPG METHOD IMPROVING BUSINESS GAMES
}

\author{
Paulo Henrique Pinho Oliveira \\ CEFET-RJ, Brazil \\ E-mail:p_h_oliveira@yahoo.com.br
}

Submission: 08/05/2017

Revision: 22/05/2017

Accept: 28/06/2017

\section{ABSTRACT}

The business game methodology is applied for the best universities in the world and has been improved itself throughout the years. Using simulated backgrounds, the players live some experiences that could live in their professional future and take decisions to have success in the game. As all research stream, business game's evolution not only has to prove your methods and benefits, but also has to know your criticisms. This paper studies these criticisms about the teaching model, specifically the fact that a round of decisions forces the student to take a decision, without he or she realized the real necessity of it. A business game literature review is needed so, and also about some parallel themes that could increase the knowledge and identify news alternatives for the criticisms, mainly about the role-playing-games method characteristics, proposing a new direction for the following researches focusing the improvement of the learning based in games.

Keywords: business game; role-playing-games; experiential learning; learning styles 


\section{INTRODUCTION}

Nowadays, most of all universities already agree that the teaching method based in business games presents a significant gain in the development of the students; either through participation in the team, the content presented or the development of new skills. Several authors presented their researches identifying different types of games that are used by the world, each type of game focuses on developing a specific activity.

In terms of Alves (2015), for example, there are many ways to classify the games, one of them is presented by author showing the differences based in yours origins: war games, role playing games (RPG) or business games. He classified in this way:

- War games: the players have to plan war strategies for military units, sometimes it is simulating some historical facts and others is about fictional wars. The main objective is destroy the opponent, each player has to think about the best strategy during the rounds to have success.

- Role-Playing Games: Essentially, it is a interpretative game, the players take a character to explore the game's scenario. This method has some similarities with a case study, when decisions still have to be taken and the student will decide what to do. It is used to be the most loved characteristic for the players about this kind of game, there are some unresolved problems and the student has different ways to solve the situation. In addition, this game model doesn't have rounds to decide, the environment is exploit according to the player's decisions and the situations appears naturally.

- Business games: it is a specific simulation, during a limited period, about the corporative issues. For example, there are some games focused in the supply chain problems, or others simulating the marketing decisions, or even some others games that simulates the general complexity to manage an organization. In this case, the players become business executive of a fictional company, and the goal is take many decisions to have the best net profit. This is the most used kind of simulator, in the universities because the less complexity to create the simulation compared with the previous one, 
when a situation is chosen to be explored by simulation, many others parameters will be considered irrelevant like a background.

Santoro (2011) wrote that choose the best teaching method is not a simple task, it most consider the content, the lessons, the teacher and the students. The best method is that most add good results in the student's learning. However, the benefits of this teaching methodology based in games are not a unanimity.

This is not about discard everything the authors have written, but there are some others authors that showed some criticizes, that should contribute to the development and improvement of this teaching method. Fernando Pretto is one of them, in his doctoral thesis presented some arguments about the possibility of have better learning using a simulation that doesn't have decisions rounds, in others words, the critical point is the fact that in traditional business game the player have to decide something in each round.

In the same point, Patz (1988) was questioning about an open system model, when the players must realize the real necessity to take a decision. Pretto's conclusion was favorable to the proposal model by the students, but the quantitative results didn't showed a real gain comparing with the rounds model.

The point approached by Patz (1988) and Pretto (2006) shouldn't be totally ignored, because highlighted a very interesting possibility to improve the business games' results, mainly after the students support in Pretto's research. The question now is: How to do a game with these characteristics having a real gain on the student learning? A possible answer is the RPG methodology, the open system to be explored by the players should give a new level of learnings in the game.

"The RPGs applications in business games had been restrict and unpopular. Probably because it is very difficult to create all the RPG rules, and the classroom usage is similar a case study or group dynamics." (Alves, 2015)

\section{JOGOS DE NEGÓCIOS}

After the end of the Second World War happened a gradual transfer of the war concepts and strategies for the business analysis. During the following years the strategists was creating many of analogy between the war situations and the business competition, market's domination, logistic, etc. However, It was really hard at that time to test News ideas and News strategies, because it was not a physics 
laboratory where it's possible to control all the variables to do an experiment, it was a much more complex situation with many variables.

In the beginning, the solutions was using case studies and some basic programs, according to Alves (2015), in the end of XX century with technology development and the computer's creation the business games had the biggest opportunity to grow up as test platform to analyze that unsolved questions. According to Gramigna (1993), the first business game was the "Top management Decision Simulation", created in the USA at 1950 to improve the knowledge about financial area.

To clarify the concept, Goldschimidt (1997) summarize the business games as a sequential exercise of taking decisions, inside a structural model of an organization, where the players become the company's managers. The same author in another time said that a simulation is the manipulation of a dynamic model, with the objective to analyze the variables relations with player decisions (GOLDSCHIMIDT, 1983).

In others words, it is an analogy that should be the most similar of the reality, to take a predictive analysis about something can happens in the real world. The business games, or business simulations, can be explained as mathematics models of determined situation of business, that the players could manage your team during some sequential rounds. (LACRUZ, 2004; BEPPU, 1984; ROCHA, 1997; TANABE, 1977; SCHAFRANSKI, 2002).

Rocha (1997) gave the credit of the business games' improvement to the study of operational research, mainly as an increase of the complexity of the mathematic model becoming more realistic. Another big contribution was the computer's technology evolution, it allowed the creation of many virtual simulations with the highest levels of complexity it ever had.

Keys e Wolfe (1990) presented files that, in the USA, in the year 1961 was created more than 100 different games in the academy, allowing that more than 30 thousands executives were trained. The same authors, in the 1980 updated that number to 1.500 games being used in the universities and companies.

"During a seminar in March 1996, at the First Conference about business game in Brazil, the conference's coordinator said that the most of the business games software was in the USA or Europe, but there was some 
people beginning good Jobs in Brazil, and with some international conferences happening in Brazilian locations, the promotion of the method has been growing even in the business market as in the educational world." (PRETTO, 2006)

Falcão and Vila (2002) presented a new way to classify the games in five categories based in its classroom function: "Triggers and inclusion games" focused to integrate the teams; "Reliable Games" to improve interpersonal relationship; "Creativity Games" focused to connect the experiences during the games and the professional experiences; "Management Games" simulate the corporative issues and decisions; and "Ending games" consolidate the lessons acquired.

For Goldschimidt (1983), doesn't matter the category of the simulation or the classifications of each author, in all situation is needed a mathematic model. The same author these models used to have three main objectives: 1) represent a real system, or we can say an ambience; 2) scenario analysis and its parameters; 3) the knowledge acquired about the simulated theme.

Some authors as Hazoof (2004) and Sauaia (1995), realized in your researches with the students of different business games that the most important things to improve the learning process and players satisfaction are:

- Ability of to adapt to new situations;

- Capacity to diagnose the problems;

- Development over the decision process;

- Problem solving.

Sauaia (1995), Schafranski (2002), wrote about the student that participate of a simulation become an activity part of the events, that wasn't happening with the previous methodologies when the students was only a spectator, now the student has feelings and emotions during the rounds of simulation. However, the same authors highlighted that this experience is not the reality, because the simulation has a controlled environment with limited variables.

To begin a business simulation, and start the taking-decision process, there are five requirements according to Churchman, Ackoff and Arnoff (1957) mentioned by Santos (1992):

- The player has to realize the problem, and the necessity to do something; 
- An objective definition for the game;

- At least two alternatives must be possible to solve the problem and achieve the goals;

- A few level of uncertainty and doubts about the alternatives;

- A problem that looks like a real issue.

This point validate the main objective of this paper that the traditional business games can lose one of the essentials characteristics of the corporative issues when the player is forced to take decisions in rounds, without had realized the real necessity to do something at that moment of simulation. Engel, Blackwell e Miniard (2000) also confirms that the beginning of the decision-making process is the recognition of some necessity. The authors wrote that it only happens when the student realize the difference of the situation at that time and the desired situation.

Based on all the previous concepts it is possible to believe the characteristics of an open system offered by RPG model, working together with a business model and enabling the players live the best experience learning, even approaching different themes and lessons in a university discipline.

\section{ROLE-PLAYING GAMES}

\subsection{The origin of RPG}

At the beginning of the 70th, in the USA, the brothers Gary Gygax and Dave Arneson did a crossover the war games to an interactive game, where the players did not control hole army any more, but now it's only a character in the new game. Come up the first RPG "Dungeons \& Dragons", it was about a medieval game as others war games, but with some breakthrough ideas.

The game gave to the player the real control of a character and a full fictional universe to be explored, based on J.R.R. Tolkien writings. Over the years, new authors was emerging and new games was created based on the literature, or history based or even based on mythology.

The first RPG based on science fiction was created in 1977, "The Traveller" had real innovating parameters with a new complex system of rules, with interstellar travels, intergalactic market and combat. The main difference was the less stiffness 
on the character's rules, stimulating the players' creativity without been limited by many rules.

In 1988, Steve Jackson created RPG GURPS (Generic Universal Role Playing System), presenting a rule's compilation that must be able to play in every scenario. The GURPS seems to be a good alternative to be used by the Business RPG, suggested by this paper.

\subsection{RPG's characteristics}

Every game must have at least a few instructions about your rules, but the biggest difference between RPG and the others is the complexity of the information detailed in the book of rules. For an example, the most famous "Dugeons \& Dragons" has three basic books without them it is impossible to play. In these books, it's not only a handbook, but all the descriptions needed to understand the entire universe, the history, geographic characteristics, economic, always full of details.

Another important characteristic of these games are the character's profile, these cards have the specific abilities, gifts, weaknesses, and physical appearance in some games to allow the player's interpretation during the simulation. Some characters in the game don't have a human control, and the profile determines the behavior of these characters.

To start RPG match is needed a previous preparation of the moderator, when is shown the main information about the scenario, while the others players must follow the instructions, and the decisions are essentially free. According the players decisions, the moderator presents the results of those actions and the environment evolution, and then the game proceed based on the players decisions.

For Shick (1991), a real RPG book must be an interactive story, and because of this point the author said that a few games could be classified as a real RPG. He called of "almost RPG" the board games that have pieces and cards guiding the player's decisions. Taking these arguments it will be harder to create a business RPG model with this interactivity.

Another essential characteristic for RPG is the quantitative decisions, in other words, the rules must be clear about all the players and the model needs a logical thinking about the possible actions. Initially this is not a problem for a business RPG thinking about financial parameters of the organizations. 
DOI: 10.14807/ijmp.v9i1.669

\title{
4. EXPERIENTIAL LEARNING
}

Before the proposal of any new learning methodology, also in businesses games, it is needed to better understand the human behavior and the learning theories:

\begin{abstract}
"According to the behavior, interests, attitudes, skills and knowledge that characterize any human being, its essential to understand the learning process, because together with the maturity are the most important influence to the human." (CAMPO, 1987, BIGGE, 1977 HILGARD, 1976, mentioned by PRETTO, 2006)
\end{abstract}

Kolb's theory (Kolb, 1984) about the experiential learning says that the behavior changes happens when a person is totally engaged in an task, analyses it and take a significant insight to apply in your decisions to have good results. Kolb's model (picture 1) is presented by the four steps of the experiential learning cycle; however, it is important to say that sometimes people doesn't have all the abilities for each step.



It is possible to realize a strong alignment between the cycle's steps and the benefits of the teaching methodology based in business simulations. This association between the business games and experiential learning had already mentioned by HAZOFF (2004), SAUAIA (1995) and SANTOS (1999).

The vertical axis has the "concrete experiences", what means the feelings about real situations that person had already lived or felt; on the other side of the axis there is "abstract conceptualization" referring to the ability of learn new informations, rationally analyzed without emotional influences.

The horizontal axis has on the right the "reflective observation" referring to the situations that needs to been analyzed, think about the variables and available 
alternatives; while on the left side of the axis there is the "active experimentation", referring to the situations to act without planning, follow the intuitions.

\subsection{LEARNING STYLES}

Kolb had used a survey, known by "Kolb Learning Style inventory", that allowed the categorization of the students with some similarities in their learning processes, the author summarized that research presenting four generic learning styles. In others words, through the personal preferences during the learning processes the author had analyzed the behavior of each student. These four styles are illustrated on picture 2, inside of Kolb's cycle:

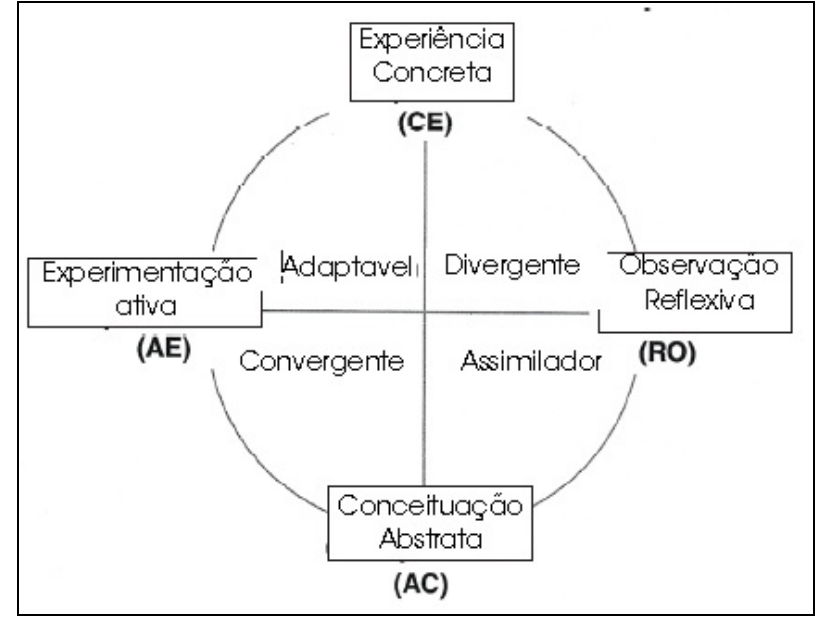

Figura 2: Kolb's learning styles.

On the top-right, there are people who prefers to learn with real experiences, most all need to realize how that content will be used in the future. This kind of student needs a encouraging teacher, because they like to "think out of the box" and usually have the most creative solutions. That's why they are called by Divergers. (KOLB, 1999A; BOYATZIS; KOLB, 2001).

\footnotetext{
"An excessive polarization of the alternatives can inhibit taking decision process of the Divergers; they seems to be better for the service organizations or for arts. The underprivileged of this style have some difficulties to realize problems or opportunities. " (PEREIRA, 2005).
}

On the bottom-right there are the theorists, or assimilators, they are people who takes your decisions based in logic, but needs some time to a reflective analyze of the problem. The teacher only needs to be near helping to understand some informations and the logic of the situation. Usually they are scientist professionals. (KOLB; KOLB, 1999a, p. 5). 
"If the assimilator characteristic was real strong, the trend is to be always thinking and unable to apply the knowledge in real situations. In contrast, the less assimilator style are unable to learn with the mistakes and systematically don't look for the problems." (CERQUEIRA, 2000).

On the bottom left side, there are the convergers. This is literally opposite of the divergers, they use the abstract concepts to have a real experience. They are technical oriented people, more practice than theory, the popular "trial and error", these students are more favorable to the simulations, or laboratory tasks. The teacher must be coach for them, creating a good atmosphere to allow them to take the risk, as the situation was real. (KOLB; KOLB, 1999a, p. 5).

On the top left, there are the "activists", they needs a real experience to take future decisions as active experimentation. Most of all are people who prefer site activities, insightful tasks, this learning style is very usual for the entrepreneurs who take the risk with decision based on feelings not planning. The teacher must be a facilitating agent to improve the opportunities, leaving the students to take themselves the connections of the theory and practice. Usually they have leader characteristics, practicality and propensity to take more risks. (KOLB, 1999).

\section{A NEW BUSINESS GAME}

It is always welcome on the academic programs a new way to do business simulations improving the students experience, the more realistic it's possible. However, the proposal of a new methodology based in RPG brings some inevitable questions about its applicability, this is the main objective of this paper, start a new discussion about the future of the business games.

The first question, maybe the most important, is how to create a RPG scenario and rules simulating the corporative issues, without lose the player's freedom in action on RPG? Surely the complexity of this proposal demand much more studies and lot of hours developing the book of rules, but it doesn't seem to be impossible to take some concepts used by famous games as "SinCity" or "Tycoon". These games created a fantastic scenario to the players manage by themselves their city, or company, with so many features that it seems to be free. As the time comes on in the simulation, the problems or opportunities happens naturally.

A second question may be done about the educational applicability and viability of this open model in the classroom, in other terms, how to make sure that all the students have gone through all the situations was planned? Certainly, the 
INDEPENDENT JOURNAL OF MANAGEMENT \& PRODUCTION (IJM\&P)

http://www.ijmp.jor.br

v. 9, n. 1, January - March 2018

ISSN: 2236-269X

DOI: 10.14807/ijmp.v9i1.669

most important peculiarity of RPG is the open scenario to be explored, and it should have a big effect on the simulation time of each student to achieve the knowledge desired by the teacher.

Maybe we can think about different stages, with specifics goals through the main objective of the entire simulation; the problem is that each student still have different difficulties and time to solve all the problems and that is why the RPG methodology does not look so good to replace the traditional business games, specifically to be used in the classrooms.

Which does not mean discard everything was showed, but in fact, it should stand a new applicability for the business games thinking about gamification trends. It's not so hard to think a training program, medium or long term, that is based on RPG rules. According to the players evolution the contents will grow together and more sophisticated.

At this point, we also can think about a game specific created to be used as a continuous human resources program, where the company could promote the organizational culture and give challenges to some employees to improve a specific knowledge, replacing the traditional training for a "connected training".

Another question should be done about the tools, some authors are board game fans and others prefers the computer software. Each one have advantages and disadvantages, the board games would allow more participation, maybe it would have more free decisions stimulating the students' creativity.

However, board games are not indicated for big teams as the universities teams are. In addition, to calculate all the variables and its effect would take much time and the game would be less dynamic for the students. A software, even online or offline, have a bigger advantage in the players capacity and the calculating process agility.

The weakness is the complexity to do a real open scenario, as mentioned in the previous questions, it must be have many options and tools to get freedom feeling. Even in the mentioned games (Sincity and Tycoon) the player has a restricted variety of choices, but they are so many developed with so many choices that the player rarely thinks about an uncover option. 
At the end, a last question should be about characters abilities, which are essentials for the RPG methodology. A good possibility to do that is by using the learning styles to create a survey to identify the player profile in the beginning of simulation. Each student should answer the questions, identifying your abilities and weaknesses to be improved during the simulation. This point would be very interesting for the HR area, to analyse the development of each employee, and even a psychology analysis for the promotions.

\section{FINAL CONSIDERATIONS}

The business game as teaching methodology has already been established in graduation or postgraduate courses all over the world, certainly these simulations continue to be improving, in technological issues or in the variety of variables approached, and it is fact that the academic community will be always looking for an upgrade of teaching quality and better learning experience.

Due to this theme diversity, there are many research lines that allow each one's evolution in your way, in others terms, we can say that while some authors will continue developing new war games that have an important function in strategic training in a fictional scenario. Others authors will dedicate the time to the software development, adopting much more variables inside the business simulations.

The entry of RPG on the discussion about business game means an interesting challenge, but also a good new alternative to apply the game methodology. It a new filed that is opened to teachers and academics, to plan games and more lasting training programs that could be a guide to full training programs connecting the abilities acquired in different courses.

\section{REFERENCES}

ALVES, Paulo Vicente. (2015) Jogos e Simulações de Empresas. Rio de Janeiro, Alta Books.

BEPPU, Clóvis loshike. (1984) Simulação em forma de "Jogo de Empresas" aplicado ao ensino de contabilidade. Dissertation (Master in accounting). São Paulo: FEA-USP.

BOYATZIS, R. E.; KOLB, D. A. (1991). Assessing individuality in learning: the learning skills profile. Educational Pscychology.

CERQUEIRA, Teresa Cristina Siqueira. (2000) Estilos de aprendizagem em universitários. Thesi (PhD in Education) Faculdade de Educação/UNICAMP. Campinas. 
ENGEL, J. F.; BLACKWELL, R. D.; MINIARD, P. W. (2000). Comportamento do Consumidor. Tradução de Christina Ávila de Menezes, 8. ed. Rio de Janeiro: LTC.

FALCÃO, Paula; VILA, Magda. (2002) Focalização de jogos em T\&D. Rio de Janeiro: Qualitymark Editora.

FARIA, A. A. (1997) O Uso Educacional dos Computadores: Um Estudo da Formação dos Administradores de Empresas. Dissertation (Master in Business Administration) Fundação Getúlio Vargas (FGV), São Paulo.

GRAMIGNA, M. R. M. (1993) Jogos de empresa. São Paulo: Makron Books.

HAZOFF JR., W. (2004) Aprendizagem de Administração de Materiais Centrada no participante. 2004. Dissertation (Master in Business Administration) FEA-USP, São Paulo.

HILGARD, E. R.; ATKINSON, R. C. (1976). Introdução à psicologia. In: LEITE, D. M. trad.; Atualidades pedagógicas, 100. São Paulo: Nacional.

KEYS, B.; WOLFE, J. (1990), The Role of Management Games and Simulations in Education and Research, Journal of Management, v. 16, n. 2, p. 307-336

KOLB, D. (1984). Experiential learning. Englewood Cliffs, New Jersey: Prentice Hall.

KOLB, A.; KOLB, D. A. (1999). Bibliography of research on experiential learning theory and the Learning Style Inventory. Department of Organizational Behavior, Weatherhead School of Management, Case Western Reserve University, Cleveland, $\mathrm{OH}$.

LACRUZ, Adonai José. (2004) Jogos de empresas como instrumento de capacitação de graduandos em administração: Contribuição para formação gerencial. Dissertation (Master in Economic and Business Management) Rio de Janeiro: UCAM.

LOPES, Wilma Maria Guimarães. (2002) Inventário de Estilos de Aprendizagem de Felder-Saloman: investigação de sua validade em estudantes universitários de Belo Horizonte. Dissertation (Master) Florianópolis. UFSC.

PATZ, Alan L. (1988) Integrating Simulations: A model for business policy success. Developments in Business Simulation \& Experiential Exercises, v. 15, University of Southern California.

PEREIRA, Márcia de Andrade. (2005) Ensino-Aprendizagem em um contexto dinâmico: o caso de planejamento de transportes. São Carlos: UFSC.

PRETTO, F. N. (2006). Pedagogia participativa na formação de administradores. Thesi not published (PhD). Universidade de São Paulo, São Paulo.

ROCHA, L. A. G. (1997) Jogos de Empresa: Desenvolvimento de um Modelo para Aplicação no Ensino de Custos Industriais. Dissertation (Master in Production Engineering) - Universidade Federal de Santa Catarina, Florianópolis.

SANTORO, Leonardo de Oliveira. (2011) Jogos de empresas: elaboração e validação de um jogo interdisciplinar. In Pensamento Contemporâneo em Administração magazine - Rio de Janeiro. 
SANTOS, S. L. (1992) Uma aplicação de modelos de simulação em sistemas de apoio à decisão. Dissertation (Master in Business Management) FEA, USP, São Paulo.

SANTOS, R. V. (1999) Jogos de Empresas Aplicados ao Processo de Ensino e Aprendizagem de Contabilidade. Thesi (PhD Business Management) FEA-USP, São Paulo.

SAUAIA, A. C. A. (1995) Satisfação e Aprendizagem em Jogos de Empresas:

Contribuições para a Educação Gerencial. Thesi (PhD in Finance and Marketing) Faculdade de Economia, Administração e Contabilidade, Universidade de São Paulo.

SCHAFRANSKI, L. E. (2002) Jogos de Gestão da Produção: desenvolvimento e validação. Thesi (PhD in Production Engineering) UFSC, Florianópolis.

SCHICK, L. Heroic (1991) Worlds: A History and Guide to Role-Playing Games. Prometheus Books, Buffalo, N.Y.

TANABE, M. (1997) Jogos de Empresas. Dissertation (Master). FEA-USP. São Paulo. 